\title{
Faktor Risiko Refrakter Trombosit pada Anak
}

\author{
Jonliberti Purba, ${ }^{*}$ Sri Mulatsih, ${ }^{*}$ Neti Nurani, ${ }^{*}$ Teguh Triyono ** \\ * Bagian Ilmu Kesehatan Anak FK UGM/RSUO Dr Sardjito Yogyakarta \\ ** Bagian Patologi Klinik /UPTD RSUP Dr Sardjito Yogyakarta
}

\begin{abstract}
Latar belakang. Transfusi trombosit sering dilakukan pada pasien anak. Namun transfusi trombosit memiliki risiko terhadap pasien dan menambah biaya perawatan, sehingga perlu dievaluasi.

Tujuan. Menilai faktor risiko klinis yakni sepsis, splenomegali, DIC, perdarahan berat dan riwayat transfusi trombosit terhadap kejadian refrakter trombosit.

Metode. Penelitian kasus kontrol untuk menilai faktor risiko terjadinya refrakter trombosit seperti sepsis, DIC, splenomegali, perdarahan berat, dan riwayat transfusi trombosit.

Hasil. Selama periode Agustus 2010 sampai September 2011 terdapat 1403 kasus transfusi dari keseluruhan kasus tersebut ditentukan 86 kejadian refrakter dan 86 nonrefrakter. Analisis bivariat mendapatkan sepsis [OR 5,91 (2,90-12,05), p=0,000], splenomegali [OR 2,82 (1,32-6,04.12), p=0,006] perdarahan berat [OR 8,41(4,19-16,871), $\mathrm{p}=0.000]$, DIC [OR 2,96 (6,73-78,35), $\mathrm{p}=0,000]$ riwayat transfusi trombosit [OR 5,33(2,78-10,23), $\mathrm{p}=0,000]$ meningkatkan risiko refrakter trombosit. Pada analisis multivariat sepsis (OR 2,96 [95\%IK; 1,19-7,32], p=0,019), splenomegali (OR 3,94 [IK 95\%;2,21-16,00], p=0,000), perdarahan berat (OR 3,53 [IK 95\%; 1,40-8,89], p = 0.008), DIC (OR 5,54 [IK 95\%; 1,29-22,75], p=0,021) dan riwayat transfusi trombosit(OR 2,84 [IK 95\%; 2,74-9,77], $\mathrm{p}=0$,001) merupakan faktor risiko independen terjadinya refrakter pada anak.

Kesimpulan. Sepsis, splenomegali, perdarahan berat, DIC dan riwayat transfusi trombosit merupakan faktor risiko terjadinya refrakter trombosit pada pasien anak. Sari Pediatri 2013;15(3):190-4.
\end{abstract}

Kata kunci: refrakter trombosit, faktor risiko, anak

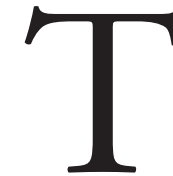

ransfusi trombosit dapat mengurangi kejadian perdarahan fatal dan menghentikan perdarahan pada anak yang terjadi akibat trombositopenia. ${ }^{1}$ Transfusi memberikan

\footnotetext{
Alamat korespondensi:

Dr. Jonliberti Purba. Bagian Ilmu Kesehatan Anak, Fakultas Kedokteran Universitas Gadjah Mada/RSUP.Dr.Sardjito, Jalan Kesehatan No. 1 Sekip Yogyakarta 55284, Indonesia. Telp. (0274) 561616, Fax. (0274) 583745, E-mail: jonliberti_purba@yahoo.com
}

risiko kepada pasien seperti penularan berbagai patogen, demam, memicu anafilaksis dan aloimunisasi sehingga sangat penting untuk mempertimbangkan keuntungan, dan kerugian transfusi trombosit. ${ }^{2}$

Efektifitas transfusi trombosit perlu dievaluasi untuk mengetahui manfaat transfusi, atau untuk menentukan tindakan selanjutnya terhadap pasien dengan trombositopenia. ${ }^{3}$ Kondisi klinis pasien yang memengaruhi efektifitas transfusi trombosit adalah sepsis, splenomegali, perdarahan berat, disseminated 
intravascular coagulation (DIC), penggunaan obatobatan yang menginduksi destruksi trombosit seperti heparin dan ampoterisin B; serta riwayat transfusi trombosit yang memicu terbentuknya antibodi antitrombosit baik antibodi anti human leucocyte antigen (anti-HLA) atau antibodi anti-human platelet antigen (anti-HPA). ${ }^{4}$

\section{Metode}

Penelitian kasus kontrol tidak berpasangan untuk menilai sepsis, splenomegali, perdarahan berat, DIC dan riwayat transfusi trombosit sebagai faktor risiko terjadinya refrakter trombosit pada anak yang menerima transfusi trombosit. Efektifitas transfusi trombosit dinyatakan dengan ada atau tidaknya refrakter terhadap transfusi trombosit yang ditentukan dengan corrected count increment (CCI) 1 jam pasca transfusi $<5000$ atau CCI $<250016-24$ jam pasca transfusi atau pagi hari pada hari berikutnya pasca transfusi. ${ }^{2,5}$ Kasus adalah pasien yang pernah mendapatkan transfusi trombosit dan refrakter, sedangkan kontrol adalah pasien yang pernah mendapatkan transfusi trombosit dan nonrefrakter. Data diambil dari rekam medis RSUP Dr Sardjito, Yogyakatra dari 1 Agustus 2010 sampai 30 September 2011.

\section{Hasil}

Selama periode 1 Agustus 2010 sampai 30 September 2011 terdapat 1403 transfusi trombosit terhadap 467 pasien. Didapatkan 86 kejadian refrakter dan 83 kejadian nonrefrakter yang memenuhi kriteria penelitian. Semua diagnosis didasarkan pada pemeriksaan angka trombosit 24 jam atau pagi hari pada hari berikutnya setelah transfusi trombosit. Setiap pasien dapat memiliki faktor risiko lebih dari satu pada saat yang bersamaan seperti pada pasien dengan sepsis dapat dijumpai splenomegali, DIC dan/atau perdarahan berat serta riwayat mendapatkan transfusi trombosit sebelumnya (Gambar 1).

Tabel 2 menunjukkan analisis bivariat pengaruh antara refrakter trombosit dengan sepsis, splenomegali, penrdarahan berat, DIC, dan riwayat

\begin{tabular}{lccc} 
Tabel 1. Karakteristik subyek penelitian & & & \\
\hline Karakteristik dasar & $\begin{array}{c}\text { Refrakter } \\
(\mathrm{N}=86)\end{array}$ & $\begin{array}{c}\text { Non refrakter } \\
(\mathrm{N}=86)\end{array}$ & $\mathrm{p}$ \\
\hline $\begin{array}{l}\text { Jenis kelamin } \\
\text { laki-laki }\end{array}$ & 50 & 47 & 0,645 \\
$\quad$ perempuan & 36 & 39 & \\
Umur (tahun) & & 52 & 0,229 \\
$0-5$ & 57 & 17 & \\
$5<10$ & 21 & 17 & $0,000^{*}$ \\
$>10$ & 8 & 40 & $0,006^{*}$ \\
Sepsis & 72 & 12 & $0,000^{*}$ \\
Splenomegali & 27 & 17 & $0,000^{*}$ \\
Perdarahan berat & 58 & 3 & $0,000^{*}$ \\
DIC & 39 & 27 & \\
Riwayat transfusi trombosit & 61 & & \\
\hline
\end{tabular}

${ }^{*} \mathrm{p}<0,05$ secara statistik bermakna

Tabel 2. Analisis bivariat faktor risiko refrakter trombosit

\begin{tabular}{lcccc}
\hline Karakteristik dasar & $\begin{array}{c}\text { Refrakter } \\
(\mathrm{N}=86)\end{array}$ & $\begin{array}{c}\text { Non refrakter } \\
(\mathrm{N}=86)\end{array}$ & OR $(95 \% \mathrm{IK})$ & $\mathrm{p}$ \\
\hline Sepsis & 72 & 40 & $5,91(2,90-12,05)$ & $0,000^{*}$ \\
Splenomegali & 27 & 12 & $2,82(1,31-6,04)$ & $0,006^{*}$ \\
Perdarahan berat & 58 & 17 & $8,04(4,19-16,87)$ & $0,000^{*}$ \\
DIC & 39 & 3 & $22,95(6,72-78,35)$ & $0,000^{*}$ \\
Riwayat transfusi trombosit & 61 & 27 & $5,33(2,78-10,22)$ & $0,000^{*}$ \\
\hline
\end{tabular}

${ }^{*} \mathrm{p}<0,05$ secara statistik bermakna 
1403 kasus transfusi trombosit

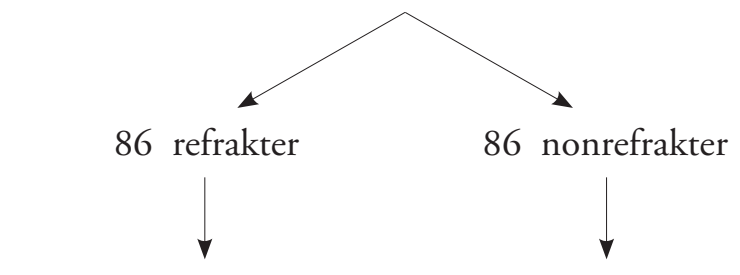

- 72 sepsis

- 27 splenomegali

- 58 perdarahan berat

- 39 DIC

-40 sepsis

- 12 splenomegali

- 17 perdarahan berat

-3 DIC

- 61 riwayat transfusi trombosit riwayat transfusi trombosit

sepsis meningkatkan risiko refrakter trombosit 2,9 kali, splenomegali 3,9kali, pendarahan berat 3,5 kali, DIC 5,5 kali, dan riwayat transfusi trombosit 2,8 kali.

Dari keseluruhan transfusi yang memenuhi kriteria penelitian, kelompok refrakter terdiri dari 50 laki-laki dan 36 perempuan sedangkan kelompok nonrefrakter terdiri dari 47 laki-laki dan 39 perempuan. Kemaknaan perbedaan jenis kelamin tidak dijumpai pada kedua kelompok $(\mathrm{p}=0,645)$. Pada kelompok refrakter, usia 0-5 tahun 57 kali transfusi, usia $5-<10$ tahun 21 kali periode transfusi, usia $>10$ tahun 8 kali transfusi trombosit, sedangkan pada kelompok nonrefrakter usia 0-5 tahun 52 kali transfusi, usia $5<10$ tahun $17 \mathrm{kali}$ transfusi, usia $>10$ tahun 17 kali transfusi trombosit. Kemaknaan perbedaan usia tidak dijumpai pada kelompok refrakter dan nonrefrakter $(\mathrm{p}=0,229)$.

Gambar 1. Alur pengambilan sampel

Tabel 3. Analisis multivariat faktor risiko refrakter trombosit

\begin{tabular}{lcccc}
\hline Karakteristik dasar & $\begin{array}{c}\text { Refrakter } \\
(\mathrm{N}=86)\end{array}$ & $\begin{array}{c}\text { Non refrakter } \\
(\mathrm{N}=86)\end{array}$ & OR $(95 \% \mathrm{CI})$ & $\mathrm{p}$ \\
\hline Sepsis & 72 & 40 & $2,96(1,19-7,32)$ & $0,019^{*}$ \\
Splenomegali & 27 & 12 & $3,94(2,20-16,00)$ & $0,000^{*}$ \\
Perdarahan berat & 58 & 17 & $3,53(1,40-8,89)$ & $0,008^{*}$ \\
DIC & 39 & 3 & $5,41(1,287-6,31)$ & $0,021^{*}$ \\
Riwayat transfusi trombosit & 61 & 27 & $2,84(1,28-6,31)$ & $0,010^{*}$ \\
\hline
\end{tabular}

${ }^{*} \mathrm{p}<0,05$ secara statistik bermakna

transfusi trombosit. Pada analisis bivariat tersebut didapatkan bahwa pasien dengan sepsis meningkatkan risiko 5,9 kali lebih besar untuk terjadinya refrakter trombosit dibanding pasien tanpa sepsis [OR 5,91 (2,90-12,05)], $\mathrm{p}=0,000]$, pasien dengan splenomegali memiliki risiko 2,82 kali lebih besar untuk terjadinya refrakter trombosit dibanding pasien tanpa splenomegali [OR 2,82 (1,32-6.04.12), $\mathrm{p}=0,006]$, pasien dengan pendarahan berat memiliki risiko 8,41 kali lebih besar untuk terjadinya refrakter trombosit dibanding pasien tanpa pendarahan berat [OR 8,41(4,19-16,871), $\mathrm{p}=0,000]$, pasien dengan DIC memiliki risiko 22,96 kali lebih besar untuk terjadinya refrakter trombosit dibanding pasien tanpa DIC [OR 22,96 (6,73-78,35), $\mathrm{p}=0,000]$ dan pasien dengan riwayat transfusi trombosit memiliki risiko 5,33 kali lebih besar untuk terjadinya refrakter trombosit dibanding pasien tanpa riwayat transfusi trombosit [OR 5,33(2,78-10,23), $\mathrm{p}=0,000]$.

Tabel 3 menunjukkan dengan analisis multivariat

\section{Pembahasan}

Keseluruhan kelompok transfusi yang memenuhi kriteria penelitian, kelompok refrakter terdiri dari 50 laki-laki dan 36 perempuan sedangkan kelompok nonrefrakter 47 laki-laki dan 39 perempuan. Kemaknaan perbedaan jenis kelamin tidak dijumpai pada kedua kelompok. Begitu pula kemaknaan perbedaan usia tidak dijumpai pada kelompok refrakter dan nonrefrakter.

Sepsis terbukti sebagai faktor risiko independen meningkatkan risiko refrakter trombosit 3 kali (OR 2,96) dibandingkan dengan anak tanpa sepsis. Hasil tersebut hampir sama dengan penelitian pada pasien dewasa dengan metode kohort prosfektif dengan risiko relatif 2,72. ${ }^{6}$ Refrakter trombosit pada sepsis terjadi melalui aktivasi protrombin oleh sitokin yang meningkat pada sepsis, selanjutnya mengaktivasi. ${ }^{6}$ Berbagai struktur bakteri seperti lipopolisakarida dan endotoksin juga mengaktivasi trombosit secara langsung. ${ }^{7}$ 
Pada sepsis juga diduga terjadi hemofagositosis terhadap trombosit. Peran magrofag diduga kuat menentukan terjadinya trombositopenia yang didukung dengan kadar magrophage colony stimulating factor (M-CSF) yang meningkat dan sebanding dengan derajat trombositopenia yang terjadi. ${ }^{6}$

Risiko refrakter trombosit meningkat empat kali pada pasien dengan splenomegali. Refrakter trombosit pada splenomegali terjadi karena sequestrasi trombosit yang meningkat sejalan dengan besarnya limpa. ${ }^{9}$ Hasil penelitian lebih besar dibanding dengan penelitian pada pasien dewasa dengan metode kohort prospektif terhadap 533 pasien yang membuktikan bahwa splenektomi dapat menurunkan kejadian refrakter trombosit sampai 25\%. ${ }^{6}$ Perbedaan tersebut disebabkan volume darah yang berada di limpa relatif lebih besar pada anak dibanding dengan dawasa. Jumlah trombosit yang berada di limpa lebih besar sebanding dengan pertambahan usia dan berat badan. ${ }^{6}$

Penurunan kejadian refrakter trombosit pada pasien yang telah menjalani splenektomi terjadi karena tidak ada trombosit yang tersequestrasi di limpa sedangkan pada pasien yang tidak menjalani splenektomi jumlah trombosit yang tersequestrasi di limpa sampai sepertiga dari jumlah trombosit yang ditransfusikan. ${ }^{9}$

Perdarahan berat meningkatkan risiko refrakter trombosit tiga setengah kali (OR 3,52) dibanding pasien tanpa pendarahan berat. Hasil penelitian kami hampir lebih besar dengan penelitian pada pasien dewasa dengan RR 2,70. ${ }^{6}$ Refrakter trombosit pada pasien dengan perdarahan berat terjadi akibat aktivasi kaskade pembekuan sebagai usaha untuk menghentikan perdarahan. Trombosit diaktivasi secara langsung akibat kerusakan endotel di lokasi perdarahan dan secara tidak langsung melalui kaskade pembekuan. Pada perdarahan berat juga terjadi pelepasan berbagai sitokin dan pelepasan tissue factor. ${ }^{1,9}$ Pada perdarahan terjadi pelepasan lipid dan fospolipid dari jaringan ke sirkulasi yang dapat memicu aktivasi sistem pembekuan. Pelepasan berbagai sitokin juga terjadi pada perdarahan masif yang juga memicu aktivasi kaskade pembekuan. ${ }^{1}$

Disseminated intravascular coagulation meningkatkan risiko terjadinya refrakter trombosit 5,4 kali (OR 5.41) dibanding pasien tanpa DIC. Hasil penelitian kami hampir sama dengan terhadap 88 pasien anak dan dewasa dengan RR 5,0. ${ }^{10}$ Pada DIC terjadi aktivasi protrombin dalam jumlah besar yang akan mengaktivasi trombosit secara langsung. Pelepasan berbagai sitokin juga akan mengaktivasi trombosit secara langsung. Kerusakan endotel yang masif pada DIC juga akan mengaktivasi kaskade pembekuan yang juga melibatkan aktivasi trombosit. ${ }^{6}$ Komponen bakteri seperti lipopolisakarida dan endotoksin juga mengaktivasi trombosit. Pengaruh berbagai jalur aktivasi trombosit pada waktu yang bersamaan merupakan penyebab DIC sebagai faktor risiko terkuat terhadap kejadian refrakter trombosit. ${ }^{11}$

Riwayat transfusi trombosit meningkatkan risiko refrakter trombosit hampir 3 kali $(\mathrm{OR} 2,84)$ dibanding pasien tanpa riwayat transfusi trombosit. Hasil penelitian kami lebih besar dari penelitian kohort prospektif terhadap 533 pasien yang dilakukan dengan risiko relatif $1,5 .{ }^{6}$ Perbedaan tersebut terjadi karena penggunaan konsentrat trombosit yang telah dilakukan proses leucoreduced, proses yang dilakukan untuk menurunkan jumlah leukosit dalam konsentrat trombosit. Proses tersebut terbukti menurunkan kejadian refrakter trombosit dari 30\% dari keseluruhan pasien yang pernah mendapatkan transfusi trombosit menjadi kurang dari $5 \% .^{5}$

Refrakter trombosit yang terjadi pada pasien dengan riwayat transfusi trombosit melalui pembentukan antibodi terhadap HPA dan HLA yang diekspresikan trombosit. Pembentukan antibodi terhadap HLA 10 kali lebih sering dibanding pembentukan terhadap HPA sehingga dapat menjelaskan penurunan risiko kejadian refrakter trombosit pada pasien yang mendapat konsentrat trombosit yang telah mengalami proses leucoreduced. ${ }^{2}$ Penelitian dilakukan dengan desain prospektif untuk menghindari bias data dan informasi. Pada penelitian kami, sebagian besar pasien yang mendapat transfusi tidak dapat dimasukkan ke dalam penelitian karena tidak dilakukan evaluasi terhadap angka trombosit 1 jam atau 16-24 jam, atau pagi hari pada hari berikutnya pasca transfusi.

Disimpulkan bahwa sepsis, splenomegali, pendarahan berat, DIC, dan riwayat transfusi trombosit meningkatkan risiko risiko refrakter trombosit pada pasien anak. Perlu dilakukan penelitiaan prospektif terhadap pasien anak tentang faktor risiko refrakter trombosit pada anak.

\section{Daftar pustaka}

1. Stroncek DF, Rubella P. Platelet Transfusions. Dalam: Transfusion medicine. Lancet 2007;2: 427-73. 
2. Refaai MA, Phipps RP, Spinelli SL, Blumberg N. Platelet transfusions: Impact on hemostasis, thrombosis, inflammation and clinical outcomes. Thrombosis Res 2011;127: 287-91.

3. Sensebe L. Factors affecting posttransfusion platelet efficiency, "close relationship between patient and product”. Transfusion Clinique et Biologique 2007;14: 90-3.

4. Marwaha N, Sharma RR. Consensus and controversies in platelet transfusion. Transfusion and Apharesis Science 2009;41:127-33.

5. Contreas M. Consensus conference on platelet transfusion. Final Statement Transfus. Sci 1998;19:111-4.

6. Slichter SJ, Davis K. Enright H. Factors affecting posttransfusion platelet increments, platelet refractoriness, and platelet transfusion intervals in thrombocytopenic patients. Blood 2005;105:105-10.

7. Levi M. Platelets in sepsis. Hematology 2005;10;12931.

8. Levi M, Meijers JC. DIC: Which laboratory tests are most useful. Blood Rev 2011;20:533-7.

9. Poala SB, Bisogno G, Colombatti R. Thrombocytopenia and splenomegaly: an unusual presentation of congenital hepatic fibrosis. Orphanet J Rare Dis 2010;5:45-58.

10. Fabris F, Soini B, Sartori R, Randi, ML, Luzatto G, Girolami A. Clinical and laboratory factors that afect the post-transfusion platelet increment. Transfusion Science 2000;23;63-8.

11. Bick LR. Disseminated intravascular coagulation. Current concepts of etiology, pathophysiology, diagnosis, and treatment. Hematol Oncol Clin N Am 2003;17: 149-76. 